\title{
Social Activity and Social Responsibility among students in the preparatory stage
}

\section{Prepared by}

\author{
Dr. Khairat Sayed Abdel Hakim \\ Dr. Salah Abdel Hakiem Ahmed Adam
}

Assistant Professor at Community Organization Department Assistant Professor at Social Work fields Department

Faculty of Social Work - Assiut University Faculty of Social Work - Assiut University 
مجلة كلية الخذمة الاجتماعية للدر اسات و البحوث الاجتماعية - جامعة الفيوك 


\section{Abstract:}

The study aimed to determine the level of social activity and the degree of social responsibility among students in the preparatory stage. It also aimed to identify the social activity most linked with social responsibility among students and to determine the relation between practicing social activity and the level of social responsibility. The study is descriptive research that applied the sample social survey methodology. The study used a social responsibility and social activity practice scale. The scale was applied to (170) individual.

The study found that the level of social activity was as follows: awareness and public service, educational meetings, trips and visits, social exhibitions, activities and improvements works, and social competitions. The level of social responsibility among students in the preparatory stage was as follows: ability to solve problems, sense of cooperation, and ethical aspects. The study also found a statistically significant positive correlation the practice of social activity and the level of social responsibility among students in the preparatory stage.

\section{Key words:}

Social activity - Social responsibility- students in the preparatory stage 
الملخص:

تعتبر جماعات النشاط المدرسي من الأدوات التي يكتسب الطلاب من خلالها المهارات الاجتماعية

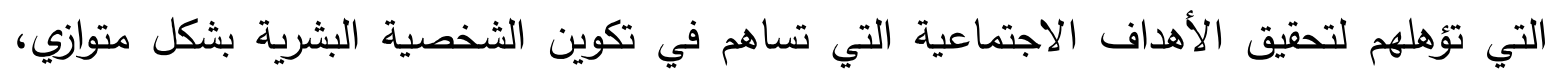

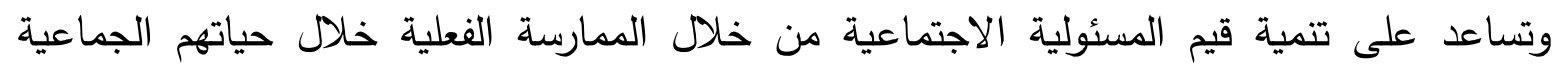

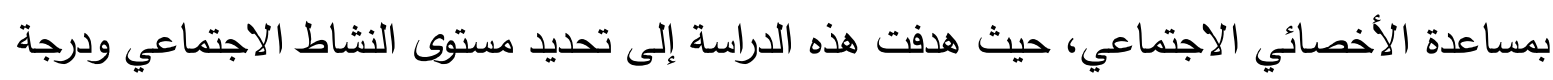

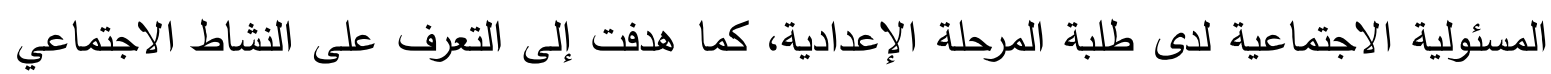

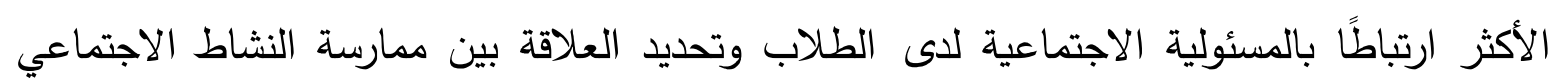

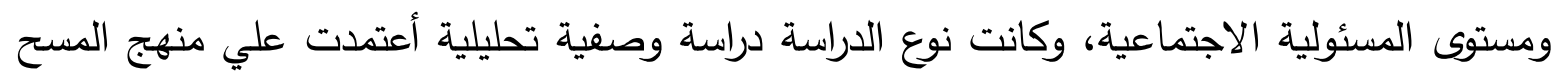
الاجتماعي بالعينة للطلاب المرحلة الاعدادية، استخدمت الدراسة مقياس الدسئولية الاجتماعية

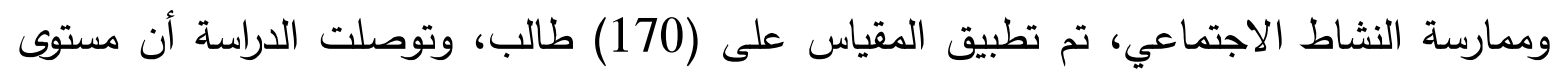

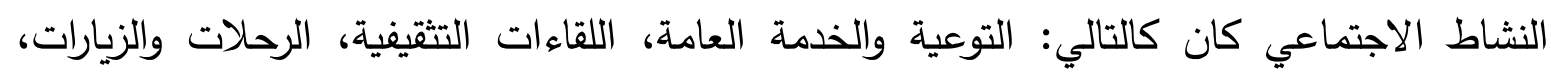
المعارض الاجتماعية ، أعمال الأنثطة والتحسينات، والمسابقات الاجتماعية، وكان مستوى المسئولية

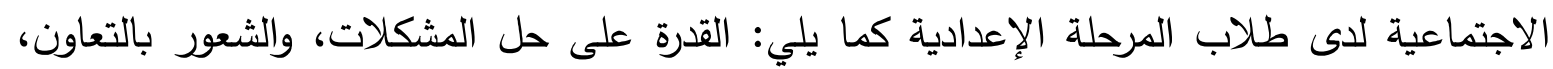
والجوانب الأخلاقية، كما توصلت الدراسة علاقة ارتباط موجبة ذات دلالة إحصائية بين ممارسة لإسة الإسة النشاط الاجتماعي ومستوى المسئولية الاجتماعية لدى طلاب المرحلة الإعدادية. الكلمات المفتاحية: النشاط الاجتماعي - المسئولية الاجتماعية-طلاب المرحلة الإعدادية 


\section{Introduction:}

The human element is one of the most important elements of development. It views children as the youth of tomorrow, the country's future, the persons responsible for the development of societies. Therefore, caring for children has become one of the most important goals that societies seek.

Focusing on children in the early age stages is focusing on the present and future of the nation, Preparing and educating children represents the necessary confrontation for the challenges of the future, A child is considered a raw material that can be formed to become a good citizen with the acquired values, customs, and traditions of the Arab society (Sherif, 2005, p. 7).

One of the main indicators for measuring the progress, development, and social growth of any society is the extent of efforts that the society exerts for the improvement of students, solving their problems, and developing their abilities with all the available means towards building responsibility among them (Fahmi, 2000, p. 30).

The school is one of the most important educational institutions for the preparation of citizens, It is the most common and widespread institution among most other social institutions, It is an institution that interacts with all students (James, 1997, p. 49). The official institution established by the State to educate young people the principles of social responsibility, morals, values and trends, and nurturing the good formation that creates good citizens who contribute to the service of their society and their nation (Naval, 2003, p. 146).

The school is where students build educational experiences in addition to daily life experiences that help them contribute effectively in their society in the future, It is one of the institutions entrusted by the community to care for its children and contribute to their development 
through sound social upbringing by providing them with positive values and constructive attitudes, It also provides them with knowledge, experiences and skills that enable them to be good citizens of their nation and society through the school activities groups (Ali, 2003, p. $63)$.

The school activity groups are one of the tools through which students acquire the social skills that qualify them, and this highlights the importance of groups of activity in achieving social goals, which contribute to the formation of human personality in parallel. (Dominic, 2001,P85).

Mansour's study examined the effectiveness of a school activities program in developing innovative thinking. He study deduced the importance of school activities in the development of creative behavior and various skills among students (Mansour, 2000). El- Me'ala's study discussed the importance of students activities in developing their characters, The study found that student activities play a major role in strengthening positive social relations between female university students, developing their hobbies and creativity, and nurturing their sense of loyalty and belonging (Al-Me'ala, 2005).

Therefore, participation in school activity groups comprehensively develops students' personality, It also helps develop the values of social responsibility through the actual practice during their group life with the assistance of the social worker (Abu El-Ela, 2007, p. 1206).

Social responsibility is a vital issue because of its association with determining actions and practices as well as the positive or negative results of said action within the social entity, Responsibility is closely related to a person's actions whether individually or within a group. Therefore, what society needs the most today is a socially responsible individual, or in other words, an individual that performs his work and 
duties, and meets his obligations without the need for instruction of supervisions from another individual or social institution.

Believing in the importance of and practicing personal, social and legal responsibility is integral to the continuity and survival of societies and individuals, and to keeping their balance and emphasizes that social responsibility is an important source for success and excellence, providing solutions to problems facing institutions such as low performance.( Abdel-Al, 2014, p. 2).

It provides a creative energy that improved the organization's competitiveness and performance, and improves its image in the society, The study recommended convincing institutions that social responsibility is a necessity in their favor, not an obligation, to be able to pursue this approach (El Hassan, 2014).

In a study recommended to those in charge of the educational process the need to include social responsibility in the educational curricula for all stages, the student acquires a sense of social and responsibility towards members of his community.(Al-Smadi \& AlBaqawi, 2015).

The process of learning social responsibility starts by the youngsters' recognition of their parents' responsibility for caring for them, raising them, and satisfying their physical and emotional needs. Responsibility gradually develops through education and upbringing whose one goal is preparing the individual to become future citizen and to be self-sufficient in meeting his/her responsibilities. Thus, we cannot marginalize the role of education in helping to nurture and develop an individual's personality (skills, training, abilities, moral and emotional sense, active will, self-confidence, entrepreneurship and professional creativity) (El Shahry, 2011, p. 52). 
Social responsibility appears in democratic relations with others and moral principles of care and justice, and contribute to some civil works. They are important in building strong societies, and thus should be nurtured in young people so that they become deeply rooted in their leadership positions (Lake\& Syvertsem, 2011).

Also, a study that used an educational program for the experimental group through the exercise of collective sports activity confirmed the highest degree of social responsibility in gaining respect, care and assistance.( Malinauskas \& , Juodsnukis, 2017).

That is why the diversity of students activities contributes to the development of social responsibility to encompass several fields. The students build knowledge of contemporary themes as well as the skills for thinking, openness to the other, self-esteem, and identifying practical solutions to problems. Activities also help identify talented students, all of which contribute to developing social responsibility (Emara, 2010, p. $125)$.

The main issue of the study as derived from the above is determined as follows: is there a relationship between social activity and social responsibility among students in the preparatory stage ?

Thus, the importance of the study lies in:

1. The necessity for focusing on students in the preparatory sage for the human force that they represent, which makes them an influential factor in society.

2. Supporting students in practicing social activities that help them assume social responsibility, which will in turn benefit society. 
3. Social responsibility is of great importance in addressing many problems facing the society in general, and preparatory schools in particular.

4. The student accepts changes that occur for development and progress.

\section{The Study Aims:}

1. Determining the level of social activity among students in the preparatory stage.

2. Determining the degree of social responsibility among students in the preparatory stage.

3. Identifying the social activity most related to social responsibility among students in the preparatory stage.

4. Determining the correlation between social activity and the degree of social responsibility among students in the preparatory stage.

\section{The Study Concepts:}

\section{- Social activity :}

Activities defined as all what an individual does and the energy that he/she exerts in group participation. Activities are also the medium through which an individual's mental, emotional, and physical growth occurs, through which the individual satisfies his/her tendencies, desires and needs, and through which he/she achieves the goals that the institution and the society regard as desirable. This occurs under the direction and care of the social worker concerned with development of social responsibility and active citizenship, while taking into account the observance of professional rules and principles (El Jumaili, 2001: 23).

\section{The social activity in this study means:}

1- Participation in educational meetings.

2- Participation in and organizing trips and visits.

3- Organizing and attending social competitions. 
4- Participating in the organization of and attending social exhibitions.

5- Participating in awareness campaigns and public service.

6- Participating in activities and improvement works.

\section{- Social Responsibility:}

The Waseet dictionary defines the responsibility in general as "the status of a person who is held accountable for a matter and its liability. It is said: "I am not liable to this action". Morally, it refers to the person's liability towards what he says or does. Legally, it refers to the obligation to correct wrongs towards others according to the law" (The Academy of the Arabic language, 1972: 411).

The dictionary of social sciences states that social responsibility focuses on the association of rights with duties. Satisfying needs and solving problems must be related to the contribution of the community members and their participation in satisfying their needs and solving their problems on their own. The social responsibility is reciprocal between individuals and groups and between local communities and the general society (Badawi, 1982, p. 395).

Another definition of social responsibility sates that it is "the commitment and obligation of decision-makers to carry out actions that will preserve and develop the society's resources, while simultaneously reaching the benefits of said resources. This means that social responsibility is realized through reaching the highest level of development of the quality of life for all community members. It means the consistency between the actions that the organization conducts for self-interest and the demands of the community" (El Rahahla, 2011: p. 65). 
Responsibility is defined as the person's preparedness to commit to an action that he conducted, recognize his responsibility for it, and 0 bear its consequences. There are several types of responsibility: social responsibility, moral responsibility, and political responsibility. Each of these types of responsibility has characteristics that distinguish it from the other types. Social responsibility generally takes on an external character because it relates to life within the group, which obligates a person to a certain conduct towards the group (El Kayyali, 1993, p. 178).

\section{Social responsibility in this study means:}

1- Commitment to different duties.

2- Group spirit and collective cooperation.

3- Ethical aspects that students practice.

4- Conducting various volunteer activities.

5- Ability to solve the problems they face.

\section{The Role theory:}

The role theory states that the individual's behavior and social relations, as well as his social status, depend on the role or social roles he occupies in society. This is because social role involves social duties and rights. The individual's duties are determined by the role he occupies, and his rights are determined by the duties and tasks he performs in society (El Hassan, 2005: 159).

According to the role theory, the process of institutionalization of social responsibility carried out by the preparatory schools is a balanced educational process that takes into account the social responsibility aspects with its various types and fields. It is practices through social activity and the distribution of different roles and task, which helps students achieve social adaptation and harmony that drives them to play 
their social roles in a balanced manner that meets the aspirations and expectations of society.

\section{The Study Methodology :}

The current study is considered a descriptive / analytical study. The social survey method is used because it is suitable to the study type and can help in collecting the required data. The study was applied on a non - random sample of students in some preparatory schools (Nasser Preparatory School, El Gam'a Preparatory School, Al Salam Preparatory School, Franciscan School)

\section{Fields of the Study:}

\section{1-The Spatial field:}

represented in the schools of (Nasser Preparatory School, El Gam'a Preparatory School, Al Salam Preparatory School, Franciscan School), and the Assiut Department of Education.

\section{2-The Human Field:}

The study sample included 170 selected students in the schools of (Nasser Preparatory School, El Gam'a Preparatory School, Al Salam Preparatory School, Franciscan School), and the Assiut Department of Education. The selection of participants was based on a non- random sampling technique.

\section{3-The Time Field:}

Data collections was conducted from 22/10/2020 to 29/11/2020.

\section{Data Collection Procedure and Ethical Considerations:}

For this study, we created and administered a scale of social responsibility among students in the preparatory stage with a cover letter explaining the purpose of the study, potential confidentiality issues, and informed consent to the respondents. Consent was obtained from each of the student. Letters were sent from the Faculty of Social Work at Assiut University to the selected schools, before distributing scale to 
students in the all sleeted schools. The data collection process lasted for 37 days.

\section{The Study Tool :}

The required data were collected by a scale of social responsibility among students in the preparatory stage.

\section{Validity and Reliability Tests :}

The value of the statistical validity coefficients of the scale for students can be determined by using the Alpha Cronbach coefficient $=$ 0.943, and Spearman Brown equation $=0.964$ on a sample of 10 students.

The reliability of the tool was calculated using Alpha Cronbach reliability coefficient $=0.89$.

\section{The Study hypotheses:}

1. The level of social activity among students in the preparatory stage is high.

2. The degree of social responsibility among students in the preparatory stage is high.

3. There is a positive correlation between the practice of social activity and strengthening social responsibility among students in the preparatory stage.

\section{Statistical analysis:}

Data were processed using the software (SPSS.V. 17.0) statistical packages for social sciences. The following statistical methods were applied:

1. Standard deviation

2. Reliability coefficient (Alpha Cronbach)

3. Pearson correlation coefficient :R

4. Selection factor $R\urcorner 2$ 
5. T-Test for two independent samples (Samples T-test independent).

The Study Results :

Demographic Information

Table (1)

Demographic Characteristics of the Sample $(n=170)$

\begin{tabular}{|c|c|c|}
\hline Characteristic & $\begin{array}{l}\mathrm{N} \\
0 \mathrm{r} \\
\mathrm{M}\end{array}$ & $\begin{array}{c}\text { standard } \\
\text { deviation } \\
\text { or } \\
\text { Percentage }\end{array}$ \\
\hline Age (in years) & 14 & 2 \\
\hline $\begin{array}{l}\text { Number of times of participation in social } \\
\text { activity }\end{array}$ & 2 & 1 \\
\hline \multicolumn{3}{|l|}{ Gender } \\
\hline Male & 95 & $55.9 \%$ \\
\hline Female & 75 & $44.1 \%$ \\
\hline \multicolumn{3}{|l|}{ Educational status of the guardian } \\
\hline without a degree & 30 & $17.6 \%$ \\
\hline Qualified average & 37 & $21.8 \%$ \\
\hline Above average qualification & 48 & $28.2 \%$ \\
\hline bachelors degree & 55 & $32.4 \%$ \\
\hline \multicolumn{3}{|l|}{ Place of residence } \\
\hline Countryside & 41 & $24.1 \%$ \\
\hline Urban & 129 & $75.9 \%$ \\
\hline
\end{tabular}

Table (1) displays the demographic information of participants.

The age of participants (M 14, SD 2). And as for the Number of times of participation in social activity (M 2, SD 1). 
The majority of participants 95 participants were male (55.9\%) and $75(44.1 \%)$ were female.

The majority of participants $55(55.4 \%)$ reported his or her parents holding a bachelor's as their parents' highest level of education, while only 30 participants $(17.6 \%)$ reported holding without a degree, $37(21.8 \%)$ reported holding middle school, $48(28.2 \%)$ high a school. Most respondents, 129 participants $(75.9 \%)$ lived in urban areas, and 41 participants $(24.1 \%)$ rural areas.

\section{The level of social activity:}

Table (2)

Level of Social Activity among Students in the Preparatory Stage

\begin{tabular}{|c|l|c|c|l|c|}
\hline No. & $\begin{array}{c}\text { Social Activity Practice } \\
\text { Level }\end{array}$ & $\begin{array}{c}\text { Arith } \\
\text { meti } \\
\text { c } \\
\text { Mea } \\
\mathrm{n}\end{array}$ & $\begin{array}{c}\text { Stand } \\
\text { ard } \\
\text { Deviat } \\
\text { ion }\end{array}$ & Level & $\begin{array}{c}\text { Rankin } \\
\mathrm{g}\end{array}$ \\
\hline 1 & Educational meetings & 2.64 & 0.4 & High & 2 \\
\hline 2 & Trips and visits & 2.6 & 0.36 & High & 3 \\
\hline 3 & Social competitions & 2.33 & 0.58 & Medium & 6 \\
\hline 4 & Social exhibitions & 2.52 & 0.43 & High & 4 \\
\hline 5 & $\begin{array}{l}\text { Awareness and public } \\
\text { service }\end{array}$ & 2.67 & 0.34 & High & 1 \\
\hline 6 & $\begin{array}{l}\text { Activities } \\
\text { improvement works }\end{array}$ & 2.45 & 0.29 & High & 5 \\
\hline Total & social activity practice \\
level & & 2.55 & 0.26 & High level \\
\hline
\end{tabular}


Table (2) indicates that the level of social activity practice as determined by students was as follows:

- In the first rank was awareness and public service with an arithmetic mean of 2.67 .

- In the second rank was educational meetings with an arithmetic mean of 2.64 .

- In the third rank was trips and visits with an arithmetic mean of 2.6 .

- In the fourth rank was social exhibitions with an arithmetic mean of 2.52 .

- In the fifth rank was activities and improvements works with an arithmetic mean of 2.45 .

- In the sixth rank was social competitions with an arithmetic mean of 2.33 .

The degree of social responsibility:

Table (3)

Level of Social Responsibility among Students in the Preparatory Stage $\mathrm{N}=170$

\begin{tabular}{||l|l|l|l|l|l||}
\hline No & $\begin{array}{l}\text { Social Responsibility } \\
\text { Level }\end{array}$ & $\begin{array}{l}\text { Arithmeti } \\
\text { c Mean }\end{array}$ & $\begin{array}{l}\text { Stan } \\
\text { dard } \\
\text { Devi } \\
\text { atio } \\
\mathrm{n}\end{array}$ & Level & $\begin{array}{l}\text { kan } \\
\text { ing }\end{array}$ \\
\hline 1 & $\begin{array}{l}\text { Commitment } \\
\text { different duties. to }\end{array}$ & 2.74 & 0.32 & High & 1 \\
\hline 2 & Group spirit and & 2.55 & 0.34 & High & 4 \\
\hline
\end{tabular}




\begin{tabular}{|l|l|l|l|l|l|}
\hline No & $\begin{array}{l}\text { Social Responsibility } \\
\text { Level }\end{array}$ & $\begin{array}{l}\text { Arithmeti } \\
\text { c Mean }\end{array}$ & $\begin{array}{l}\text { Stan } \\
\text { dard } \\
\text { Devi } \\
\text { atio } \\
\mathrm{n}\end{array}$ & Level & $\begin{array}{l}\text { Ran } \\
\mathrm{k}- \\
\text { ing }\end{array}$ \\
\hline 3 & Ethical aspects. & 2.48 & 0.36 & High & 5 \\
\hline 4 & $\begin{array}{l}\text { Conducting various } \\
\text { volunteer activities. }\end{array}$ & 2.7 & 0.35 & High & 2 \\
\hline 5 & $\begin{array}{l}\text { Ability to solve } \\
\text { problems. }\end{array}$ & 2.62 & 0.31 & High & 3 \\
\hline & $\begin{array}{l}\text { Total Students Social } \\
\text { Responsibility Level }\end{array}$ & 2.61 & 0.23 & High Level \\
\hline
\end{tabular}

Table (3) indicates that the level of social responsibility among students in the preparatory stage as follows:

- In the first rank was commitment to different duties with an arithmetic mean of 2.74 .

- In the second rank was conducting various volunteer activities with an arithmetic mean of 2.7 .

- In the third rank was ability to solve problems with an arithmetic mean of 2.62 .

- In the fourth rank was group spirit and collective cooperation with an arithmetic mean of 2.55 .

- In the fifth rank was ethical aspects works with an arithmetic mean of 2.48 . 
Results of the Study Hypotheses :

Table (4)

Correlation between practicing social activity and social responsibility among students in the preparatory stage

$\mathrm{N}=170$

\begin{tabular}{|c|c|c|c|c|c|c|c|}
\hline No & Social Activity & $\begin{array}{c}\text { Commi } \\
\text {-tment } \\
\text { to } \\
\text { differe } \\
\text { nt } \\
\text { duties }\end{array}$ & $\begin{array}{c}\text { Spirit } \\
\text { and } \\
\text { Colla } \\
\text { b- } \\
\text { oratio } \\
n\end{array}$ & $\begin{array}{c}\text { Ethic } \\
\text { al } \\
\text { Aspe } \\
\text { cts }\end{array}$ & $\begin{array}{c}\text { Cond } \\
\text { ucting } \\
\text { Volun } \\
\text { teer } \\
\text { Activit } \\
\text { ies }\end{array}$ & \begin{tabular}{|c} 
Abili \\
ty \\
to \\
Sol \\
ve \\
Pro \\
ble \\
ms
\end{tabular} & $\begin{array}{c}\text { Social } \\
\text { Responsibility as a } \\
\text { Whole }\end{array}$ \\
\hline 1 & $\begin{array}{l}\text { Education } \\
\text { meetings }\end{array}$ & $\begin{array}{l}0.425 \\
* *\end{array}$ & $\begin{array}{l}0.096 \\
* *\end{array}$ & $\begin{array}{l}0.349 \\
* *\end{array}$ & $\begin{array}{l}0.356 \\
* *\end{array}$ & $\begin{array}{l}0.0 \\
53\end{array}$ & $0.379 * *$ \\
\hline 2 & Trips and visits & $\begin{array}{l}0.509 \\
* *\end{array}$ & $\begin{array}{l}0.076 \\
* *\end{array}$ & $\begin{array}{l}0.444 \\
* *\end{array}$ & $\begin{array}{l}0.329 \\
* *\end{array}$ & $\begin{array}{l}0.3 \\
39 \\
* *\end{array}$ & $0.530 * *$ \\
\hline 3 & $\begin{array}{l}\text { Social } \\
\text { competitions }\end{array}$ & $\begin{array}{l}0.219 \\
*\end{array}$ & $\begin{array}{l}0.347 \\
* *\end{array}$ & $\begin{array}{l}0.213 \\
*\end{array}$ & 0.001 & 0 & $0.357 * *$ \\
\hline 4 & Social exhibitions & $\begin{array}{l}0.323 \\
* *\end{array}$ & $\begin{array}{l}0.271 \\
* *\end{array}$ & $\begin{array}{l}0.450 \\
* *\end{array}$ & $\begin{array}{l}0.438 \\
* *\end{array}$ & $\begin{array}{l}0.2 \\
36 *\end{array}$ & $0.473 * *$ \\
\hline 5 & $\begin{array}{l}\text { Awareness and } \\
\text { public service }\end{array}$ & $\begin{array}{l}0.664 \\
* *\end{array}$ & $\begin{array}{l}0.316 \\
* *\end{array}$ & $\begin{array}{l}0.513 \\
* *\end{array}$ & $\begin{array}{l}0.400 \\
* *\end{array}$ & $\begin{array}{l}0.4 \\
65 \\
* *\end{array}$ & $0.679 * *$ \\
\hline 6 & $\begin{array}{l}\text { Activities and } \\
\text { improvement } \\
\text { works }\end{array}$ & $\begin{array}{l}0.371 \\
* *\end{array}$ & $\begin{array}{l}0.208 \\
*\end{array}$ & $\begin{array}{l}0.566 \\
* *\end{array}$ & $\begin{array}{l}0.462 \\
* *\end{array}$ & $\begin{array}{l}0.3 \\
26 \\
* *\end{array}$ & $0.551 * *$ \\
\hline
\end{tabular}




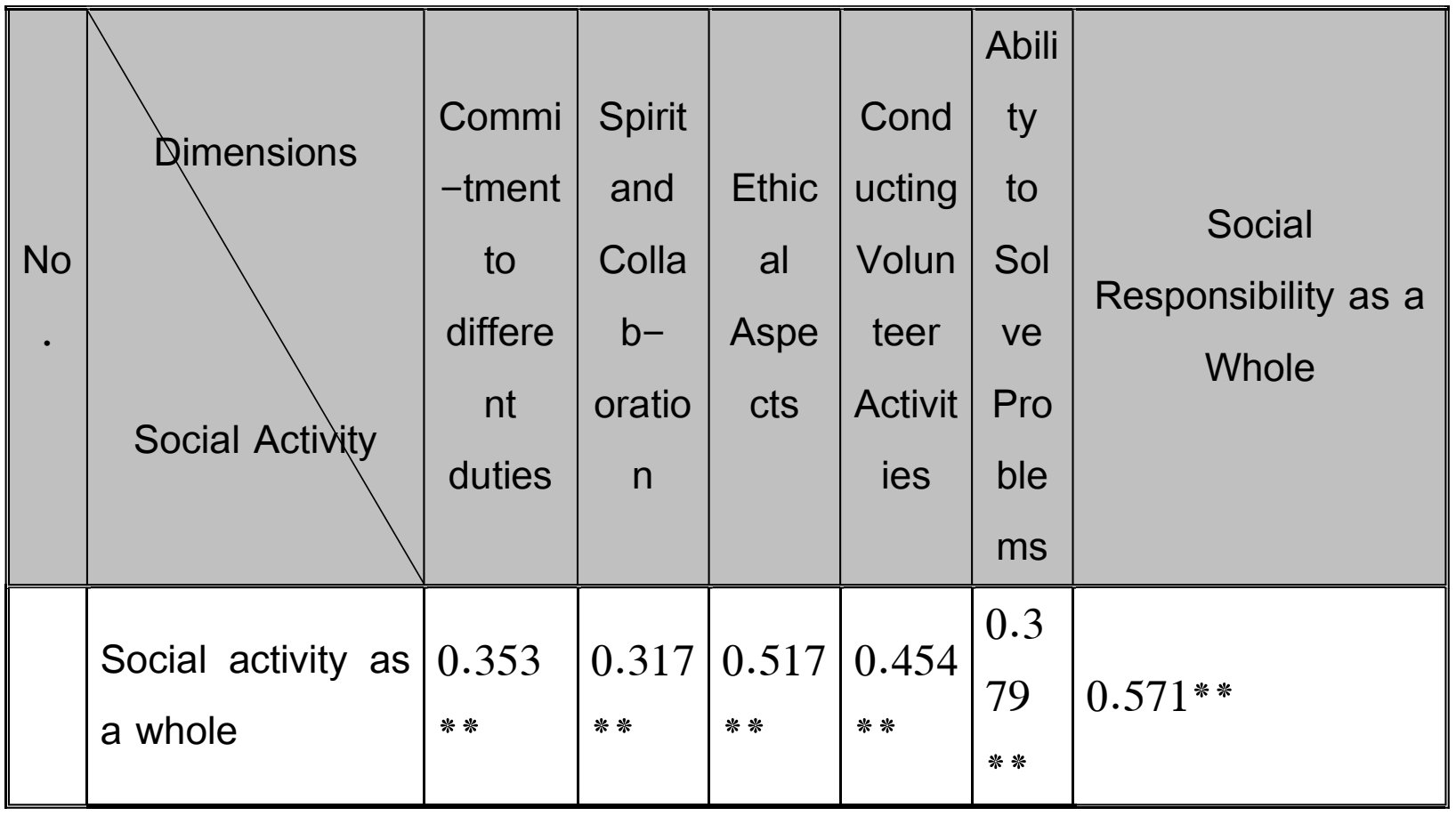

Table (4) shows that: There is a statistically significant correlation at significance level $(0.01)$ between the practice of social activity and the strengthening of the social responsibility among pupils in the preparatory stage as determined by the students. The social activity most related to social responsibility among preparatory students are in order of ranking: awareness and public service, trips and visits, activities and improvement works, social exhibitions, educational meetings, and social competitions. 
Table (5)

Analysis of the Simple Regression in the Relationship between

Practicing Social Activity and Social Responsibility among Students

\begin{tabular}{|c|c|c|c|c|c|c|c|c|}
\hline \multirow{2}{*}{$\begin{array}{c}\text { Indep } \\
\text { enden } \\
t \\
\text { Variab } \\
\text { le }\end{array}$} & \multirow[t]{2}{*}{$\begin{array}{c}\text { Regression } \\
\text { Coefficient } \\
\text { B }\end{array}$} & \multicolumn{2}{|c|}{ T-Test } & \multicolumn{2}{|c|}{ F-Test } & \multicolumn{2}{|c|}{$\begin{array}{c}\text { Correlatio } \\
n \\
\text { Coefficient } \\
\mathrm{R}\end{array}$} & \multirow{2}{*}{$\begin{array}{c}\text { Deter- } \\
\text { mination Co- } \\
\text { efficient } \\
\mathrm{R}^{2}\end{array}$} \\
\hline & & $\begin{array}{l}\text { Va } \\
\text { lue }\end{array}$ & $\begin{array}{l}\text { Signifi } \\
\text { cance }\end{array}$ & $\begin{array}{l}\text { Val } \\
\text { ue }\end{array}$ & $\begin{array}{l}\text { Signifi } \\
\text { cance }\end{array}$ & $\begin{array}{l}\text { Va } \\
\text { lue }\end{array}$ & $\begin{array}{l}\text { Signifi } \\
\text { cance }\end{array}$ & \\
\hline $\begin{array}{l}\text { Social } \\
\text { activit } \\
\text { y as a } \\
\text { whole }\end{array}$ & 0.503 & $\begin{array}{l}6 . \\
34 \\
3\end{array}$ & 0 & $\begin{array}{l}40 . \\
23 \\
6\end{array}$ & 0 & $\begin{array}{l}0 . \\
57 \\
1\end{array}$ & 0 & 0.326 \\
\hline
\end{tabular}

Table (5) shows that:

- The correlation coefficient between the independent variable "social activity as a whole" and the dependent variable "social responsibility" as determined by the students $(0.571)$ which is was statistically significant at 0.01 significance level, indicating a positive correlation between the two variables.

- The result of the $F$ test $(F=40.236$, Sig $=0.000)$ indicates the significance of the regression model. The value of the coefficient of determination reached 0.326 . In other words, practicing social activity as a whole represents $32.6 \%$ of the change that occurred in bearing social responsibility among students of the preparatory stage. This is confirmed by Atef Khalifa's study (1997) on the importance of student activities in the development of social responsibility among students, and the development of other 
social values such as loyalty and belonging, and working towards public interest.

- The value of the regression coefficient $(0.503)$, indicating a positive relationship between the independent variable and the dependent variable. The result of the $\mathrm{T}$ test $(\mathrm{T}=6.236$, Sig $=$ $0.000)$ indicates that the effect of the independent variable on the dependent variable is statistically significant at significance level 0.01 .

\section{Discussion :}

This study attempts to clarify the relationship between Social activity and social responsibility among preparatory stage students. The results of this study indicates that the level of social activity among students in the preparatory stage is high.

The results of the study tables indicate that the total arithmetic mean of the level of social activity as determined by students reached 2.55, which is considered a high level. This proves the validity of the first study hypothesis "The level of social activity among students in the preparatory stage is high". This conforms with the results of Mansour's study (2000), which pointed to the necessity of students' participation in activities in order to develop their creative behavior and skills, and to encourage bearing responsibility among them. This also conforms with Metwalli's study (1990), which emphasized the importance of student's participation in different activities.

Metwalli considered participation an obligation and a social duty. In addition, El Ma'la's study pointed to the importance of students activities in building the students' character. her study found that student activities play a major role in strengthening positive social 
relations between female university students, developing their hobbies and creativity, and nurturing their sense of loyalty and belonging.

The current study showed that the degree of social responsibility among students in the preparatory stage is high". The results of the study indicate that the total arithmetic mean of the level of social responsibility among preparatory stage students reached 2.61 , which is considered a high level. This proves the validity of the second study hypothesis "The level of social responsibility among students in the preparatory stage is high".

That is because social responsibility represents positive values that benefit the individual, group, and community. This was emphasized by El Hassan's study (2014) which considered social responsibility an important source for success and excellence, providing solutions to problems facing institutions such as low performance. It provides a creative energy that improved the organization's competitiveness and performance and improves its image in the society.

Lake \& Syvertsem (2011) noted that social responsibility appears in democratic relationships with others, in the ethical principles of care and justice, and in contributing to civil works. Social responsibility is also important in building strong societies. Therefore, it should be cultivated in young people to ensure it becomes rooted inside them in their future leadership positions. This is additionally supported by El Kayyali's study (1992), which pointed to social responsibility as an educational, moral, religious and moral issue that needs to be given attention inside institutions and social environments because of its great importance in human life.

The current study also points to there is a positive correlation between the practice of social activity and strengthening social responsibility among students in the preparatory stage. There is a 
statistically significant correlation at significance level $(0.01)$ between the practice of social activity and the strengthening of the social responsibility among pupils in the preparatory stage as determined by the students. The social activity most related to social responsibility among preparatory students are in order of ranking: awareness and public service, trips and visits, activities and improvement works, social exhibitions, educational meetings, and social competitions. This may be due the presence of a positive correlation between these variables, which reflected what the study aimed to achieve.

This proves the validity of the study third hypothesis "there is a positive correlation between the practice of social activity and strengthening social responsibility among students in the preparatory stage".

Mahrous' study (1999) examined the contributions of social responsibility to increasing students' participation in activities, increasing their sense of loyalty and belonging and their positive attitudes towards the preservation of public ownership. Khalifa's study (1997) confirmed the presence of a positive correlation between the students' participation in student groups and the development of social responsibility among them, which was represented in the emergence of the spirit of loyalty, belonging, and positive attitude towards maintain public ownership among them.

\section{The Study Suggestions and Recommendations:}

1. Expansion of social activities in the field of education, especially among school students in the preparatory sage (in the form of cultural competitions, cooperation and participation, environmental activities, and community involvement). 
2. The need to intensify governmental and civic efforts in developing social responsibility through legal and voluntary frameworks, especially for schoolchildren.

3. Giving further attention to young people and their formation to become responsible future leaders in society through assuming social responsibility, as well as providing them social activity skills.

4. Emphasizing on the participation of student $s$ in social activity, which promotes the development of their social responsibility.

5. The need for student participation in spreading the culture of social responsibility that urges altruism, co-operation, and volunteerism through programs and activities.

6. Working to develop the performance of the social worker supervising the implementation of social activities through courses, and exchange of visits and experiences.

7. Providing sufficient number of social workers to carry out school activities in creative and competitive ways between activities because of their importance in supporting the values of social responsibility belonging to the community, tolerance and work with team. 


\section{REFERENCES}

1- Aaron, J. (1997), Driver and Traffic Safety Education, Macmillan Publication, N.Y.

2- Abdel Aal, N. Farghaly (2014), Social and Cultural Determinants of Social Responsibility, a Field Study on a Sample of Egyptian Youth in Rural and Urban Areas, Ph.D., Faculty of Arts, Cairo University.

3- Abu El Ela, M. Fao (2007), The Relation between the Group Work Method Program and Developing the Values of Social Peace Culture among Youth Parliament Group, research published in the Twentieth International Scientific Conference of Social Work (Social Work between Local and Global Variables) Faculty of Social Work, Helwan University.

4- Ali, M. Abu El Maati (2003), Social Work in the Fields of Professional Practice, Cairo, Zahraa Al Sharq Library.

5- Al-Rahahleh, A. Salem (2009), Social Responsibility, Amman, Arab Society Library for Publishing and Distribution.

6- Al-Smadi, Abdul Majeed and Al-Baqawi, Aqel (2015): Differences in social responsibility among high students in Hail region, Saudi Arabia in the light of a number of variables, Jordan, Journal of educational sciences, 11(2).

7- Badawi, A. Zaki (1982), Glossary of Social Sciences - English French Arabic, Lebanon Library, Beirut, p. 395.

8- Brien, D, (2001), A Comparison of the Effeteness of Nine Methods of Different High School Activity Groups on Selected Measure of Health, United States, Sports Academy. 
9- El Hassan, E. Mohammed (2005), Advanced Social Theories, Amman, Dar Wael for Publishing and Distribution.

10- El Jumaili, F. Abdel Ghani (2001), Crime, Society, and the Perpetrator of Crime, Jordan, Dar Wael for Publishing and Distribution.

11- El Kayyali, A. (1993), Encyclopedia of Politics, Volume 6, Arab Institute for Research and Publication, Beirut.

12- El Me'alla, N. Mohammed (2005), Student Programs and Activities and their Role in Developing University Students' Personality, A Field Study, published research, The Eighteenth Scientific Conference, Faculty of Social Work, Helwan University, Vol. 6 .

13- $\quad$ El Shary, A. Amer Mohammed (2011), Social Responsibility Towards Society: A Field Study Applied to the Endowment Association in the Saudi Society, unpublished MA Thesis, EI Ryad, King Saud University.

14- El-Hassan, B. Mohammed (2014), The Role of Social Responsibility in Improving the Performance of the Organization, unpublished Master Thesis, Faculty of Economic Sciences, Commerce and Management Sciences, Mohammed Khudair University, Biskra, Algeria.

15- Emara, S. Fathi Abdel Ghani (2010), The Role of University Professor in Developing the Values of Citizenship to Face the Challenges of Cultural Identity, research published in the Future of Arab Education Periodical, Volume 17, Issue no. 64.

16- Fahmy, M. Sayed (2000), Street Children: A Civilization Tragedy in the Third Millennium, Alexandria, Modern University Office. 
17- Hassan, A. Mahmoud (2003), Social Work and Fields of

Professional Practice, Alexandria, Dar El-Maerifa El-Gamieia.

18- Lake, L. Wray \& Syvertsen, A. K. (2011), The

Developmental Roots of Social Responsibility in Childhood and Adolescence, New Directions For Child And Adolescent Development, No. 134, New York Wiley Periodicals Inc.

19- Malinauskas Romualdas K. , Juodsnukis Dalius R.(2017). Education of Social Responsibility among Sports Schools Students. European Journal of Contemporary Education, 6(2). Available in: www.ejournal1.com

20- Mansour, S. (2000), The Effectiveness of School Activities

Program in Developing Creative Thinking among Children with Hearing Disabilities, Kingdom of Saudi Arabia.

21- Naval, C., et. al. (2003), Civic Education in Spain, A Critical Review of Policy, Available in: www.socis-onlinejournal.de /2003-3/imdex.htm.

22- Sharif, S. Abdel Kader (2005), Social Upbringing of the Arab Child in the Age of Globalization, Cairo, Dar El Fekr El Araby.

23- $\quad$ The Academy of the Arabic Language, (1972), Al Waseet Dictionary, Part One, Second Edition. 
مجلة كلية الخذمة الاجتماعية للدر اسات و البحوث الاجتماعية - جامعة الفيوك 